Chapter 4

\title{
Effectiveness of Lignin-Removal in Simultaneous Saccharification and Fermentation for Ethanol Production from Napiergrass, Rice Straw, Silvergrass, and Bamboo with Different Lignin-Contents
}

\author{
Masahide Yasuda, Keisuke Takeo, \\ Tomoko Matsumoto, Tsutomu Shiragami, \\ Kazuhiro Sugamoto, Yoh-ichi Matsushita and \\ Yasuyuki Ishii
}

Additional information is available at the end of the chapter

http://dx.doi.org/10.5772/54194

\section{Introduction}

Second-generation biofuels from lignocellulosic materials have gained much attention since the lignocelluloses are not in competition with food sources and animal feed and will provide a new sustainable energy sources alternative to petroleum-based fuels (Galbe and Zacchi, 2007). Bioethanol production from herbaceous lignocellulose such as corn stover (Ryu and Karim, 2011), rice straw (Ko at al., 2009), sweet sorghum bagasse (Cardoba et al., 2010), switchgrass (Keshwani and Cheng, 2009), bamboo (Sathitsuksanoh at al., 2010), wheat straw (Talebnia et al., 2010), alfalfa stems (González-García at al., 2010), and silvergrass (Guo et al., 2008) has been extensively developed through a variety of processes combining the biological saccharification and fermentation steps with the pre-treatment methods. In almost all processes, the pretreatments to remove the lignin components and to promote an enzymatic digestibility of cellulosic components are carried out by the use of energy and cost which are frequently higher than those of bio-fuels gained (Alvira et al., 2010). If lignocelluloses with low lignin-content are selected, the operation to remove the lignin might be excluded from the bio-ethanol process.

Among the many kinds of lignocelluloses, therefore, we (Yasuda et al., 2011; Yasuda et al., 2012) and other groups (Li et al., 2011; Brandon et al., 2011; Zhang et al., 2011; Huang et al., 
2011; Lin et al., 2011a; Lin et al., 2010b; Kai et al., 2010; Anderson et al., 2008) have been interested in napiergrass (Pennisetum purpureum Schumach) which is herbaceous lignocellulose with its low lignin- content. During our investigations on bioethanol production, it was found that the alkali-pretreatment of napiergrass enhances scarcely the ethanol yield whereas the alkali-pretreatment of silvergrass (Miscanthus sinensis Anderss) remarkably enhances the ethanol yield (Yasuda et al., 2011). Here, we compared the effectiveness of lignin-removal between napiergrass and other lingocelluloses with different lignin-contents (rice straw, silvergrass, and bamboo) in order to evaluate the availability of non-pretreated napiergrass as the raw materials of bio-ethanol.

\section{Materials and methods}

\subsection{Chemical components of herbaceous lignocellulose}

The lignocellulosic materials were cut, dried, and powdered until the $70 \%$ of the particles became in a range of $32-150 \mu \mathrm{m}$ in length to promote the cellulase- saccharification and to reduce varying in components in each experiment. The lignin-contents in lignocelluloses were determined as follows. The powdered lignocelluloses $(30.0 \mathrm{~g})$ was washed with $\mathrm{MeOH}$ and treated with a $1 \%$ aqueous solution of $\mathrm{NaOH}(400 \mathrm{~mL})$ at $95^{\circ} \mathrm{C}$ for $1 \mathrm{~h}$ (Silverstein, et al., 2007; Yasuda et al., 2011; Yasuda et al., 2012). After centrifugation at 10,000 rpm for $10 \mathrm{~min}$ to separate the precipitates, the supernatant solution was neutralized to $\mathrm{pH} 5.0$ by a dilute $\mathrm{HCl}$ solution to give the lignin as a dark brown precipitate. The lignin-contents of napiergrass, rice straw, silvergrass, and bamboo were determined to be $14.9,18.2,21.7$, and $26.2 \mathrm{wt} \%$, respectively.

The holocellulose (cellulose and hemicellulose) was isolated as a pale yellow precipitate by the above centrifugation. The saccharide components of holocellulose were determined according to the methods published by the National Renewable Energy Laboratory (NREL) as follows (Sluiter et al., 2010). Sulfuric acid (72\%) was added to holocellulose and then diluted with water until the concentration of sulfuric acid became $4 \%$. This was heated at $121{ }^{\circ} \mathrm{C}$ for $1 \mathrm{~h}$ in a grass autoclave (miniclave, Büchi AG, Switerland). HPLC analysis of the hydrolyzate showed that holocellulose mainly composed of glucose and xylose along with the small amounts of arabinose and galactose. The ash component in lignocelluloses was obtained by the burning of the lignocelluloses $(2.0 \mathrm{~g})$ in an electric furnace (KBF784N1, Koyo, Nara, Japan) for $2 \mathrm{~h}$ at $850^{\circ} \mathrm{C}$. Chemical components of lignocelluloses are shown in Table 1.

\subsection{Saccarification}

As has been previously reported (Yasuda et al., 2011; Yasuda et al., 2012), a cellulase from Acremonium cellulolyticum (Acremozyme, Kyowa Kasei, Osaka, Japan) was selected by the comparison in activity with other cellulase such as Meycellase (Kyowa Kasei), a cellulase from Trichoderma viride (Wako Chemicals, Osaka, Japan) and a cellulase from Aspergillus niger (Fluka Japan, Tokyo). The cellulase activity of Acremozyme was determined by the method of the breakdown of filter paper (Yasuda et al., 2012). At first, cellulase activity was 
defined as 10,000 units when two sheets of filter papers $(1 \mathrm{~cm} \times 1 \mathrm{~cm})$ degraded at pH 5.0 and $45^{\circ} \mathrm{C}$ by the cellulase for $150 \mathrm{~min}$. The filter papers were entirely degraded in $114 \mathrm{~min}$ by 10 mg of Acremozyme. Thus, cellulase activity of Acremozyme was determined to be 1320 units $\mathrm{mg}^{-1}$ according to the following equation: cellulase activity (units $\mathrm{mg}^{-1}$ ) $=150 \times 10,000$ / $(\mathrm{a} \times \mathrm{b})$ where $\mathrm{a}$ and $\mathrm{b}$ denoted weight of cellulase in $\mathrm{mg}$ and period in min required for the degradation, respectively.

\begin{tabular}{|c|c|c|c|c|}
\hline \multirow[b]{2}{*}{ Lignocelloloses } & \multicolumn{4}{|c|}{ Components/g a) } \\
\hline & $\begin{array}{l}\text { Holocellulose } \\
\text { (hexose : pentose) }{ }^{\text {b) }}\end{array}$ & Lignin & Ash & Others \\
\hline Napiergrass c) & $57.3(37.5: 26.5)$ & 14.9 & 12.7 & 15.1 \\
\hline Rice straw & 61.3 (39.7 : 28.4) & 18.2 & 17.7 & 2.8 \\
\hline Silvergrass & $41.0(34.2: 11.4)$ & 21.7 & 4.0 & 33.3 \\
\hline Bamboo & 66.5 (43.9 : 30.0) & 26.2 & 1.4 & 5.9 \\
\hline \multicolumn{5}{|c|}{$\begin{array}{l}\text { b) The values in the parenthesis are the amounts (g) of hexose and pentose derived from } 100 \mathrm{~g} \text { of lignocelluloses. } \\
\text { c) Referred from Yasuda et al., } 2012 .\end{array}$} \\
\hline
\end{tabular}

Table 1. Components of herbaceous lignocellolosic materials

The saccharification of the powdered cellulosic materials (10.0 g) was performed with Acremozyme (1.0 g) in an acetate buffer $(60 \mathrm{~mL}, \mathrm{pH} 5.0)$ under vigorous shaking at $45^{\circ} \mathrm{C}$. At the given saccharification time, the portion was taken from the reaction mixture and centrifuged at $12,000 \mathrm{rpm}$. The supernatant solutions were subjected to analysis for saccharides. The amounts of the reducing saccharides obtained from the saccharification reactions at 30, 40, and $45^{\circ} \mathrm{C}$ were almost the same.

\subsection{Simultaneous Saccharification and Fermentation (SSF)}

Saccharomyces cerevisiae NBRC 2044 was grown at $30{ }^{\circ} \mathrm{C}$ for $24 \mathrm{~h}$ in a basal medium (initial $\mathrm{pH}$ 5.5) consisting of glucose $\left(20.0 \mathrm{~g} \mathrm{~L}^{-1}\right)$, peptone (1.0 $\mathrm{g} \mathrm{L}^{-1}$, Difco), yeast extract $\left(1.0 \mathrm{~g} \mathrm{~L}^{-1}\right)$, $\mathrm{NaHPO}_{4}\left(1.0 \mathrm{~g} \mathrm{~L}^{-1}\right)$, and $\mathrm{MgSO}_{4}\left(3.0 \mathrm{~g} \mathrm{~L}^{-1}\right)$. After incubation for $24 \mathrm{~h}$, the cell suspension of $S$. cerevisiae was obtained. The grown culture of $S$. cerevisiae showed a cell density of $7.7 \times 10^{7}$ cells $\mathrm{mL}^{-1}$.

The suspension of cellulosic materials $(1.33 \mathrm{~g})$ in an acetate buffer solution $(5 \mathrm{~mL}, \mathrm{pH} 5.0)$ was introduced into the test tube $(100 \mathrm{~mL})$ and was autoclaved at $121^{\circ} \mathrm{C}$ for $20 \mathrm{~min}$. After cooling the autoclaved suspension of cellulosic materials, the cell suspension $(0.16 \mathrm{~mL})$ of $S$. cerevisiae and the Acremozyme cellulase $(133 \mathrm{mg})$ in an acetate buffer solution ( $3 \mathrm{~mL}, \mathrm{pH} 5.0)$ were added (Yasuda et al., 2012). The glucan contents were determined to be 436, 475, 410, and $525 \mathrm{mg}$ in non-treated cellulosic materials ( $1.33 \mathrm{~g}$ ) of napiergrass, rice straw, silvergrass, and bamboo, respectively. In the case of alkali-treated cellulosic materials (1.33 g), 761 (na- 
piergrass), 774 (rice straw), 999 (silvergrass), and $790 \mathrm{mg}$ (bamboo) of the glucan contents were included. The reaction vessel was connected by tube to messcylinder set in a waterbath to collect the evolved $\mathrm{CO}_{2}$ gas. The reaction progress was monitored by the volume of $\mathrm{CO}_{2}$. Thus, the simultaneous saccharification and fermentation (SSF) process was performed by stirring vigorously the reaction mixture with a magnetic stirrer at $34{ }^{\circ} \mathrm{C}$, which is the optimal temperature.

\subsection{Analysis}

Saccharides were analyzed on a high-performance liquid chromatography system (LC-20AD, Shimadzu, Kyoto, Japan) equipped with RI detector (RID-10A) using anion exchange column (NH2P-50 4E; Shodex Asahipak, $250 \mathrm{~mm}$ in length and $4.6 \mathrm{~mm}$ in ID, Yokohama, Japan). Acetonitrile-water $(8: 2 \mathrm{v} / \mathrm{v})$ was flowed at $1.0 \mathrm{~mL} \mathrm{~min}^{-1}$ as mobile phase. As a method to supplement LC analysis of saccarides, the amount of the reducing sugars released by the saccharification process was analyzed by a modified Somogyi-Nelson method (Kim and Sakano, 1996) assuming the composition of sugars to be $\mathrm{C}_{6} \mathrm{H}_{12} \mathrm{O}_{6}$. The amounts of pentose were analyzed by a modified orcinol method using 5-methylresorcinol (orcinol), $\mathrm{FeCl}_{3} 5 \mathrm{H}_{2} \mathrm{O}$, and conc $\mathrm{HCl}$ (Fernell and King, 1953). Ethanol was analyzed by gas-liquid chromatography using a Shimadzu gas chromatograph (model GC-2014) and a glass column of 5\% Thermon 1000 on Sunpak-A (Shimadzu) with 2-propanol as an internal standard. Scanning electron microscope (SEM) images were taken on a Hitachi S-4100 (Tokyo, Japan).

\section{Results and discussion}

\subsection{Napiergrass (Pennisetum purpureum Schumach)}

Napiergrass is a herbaceous tropical species, native to the east Africa. There are wide variation of phenotypes in napiergrass, reflected by plant breeding due to the crossing of dwarf genotype and relative species such as pearl millet (Pennisetum americanum) (Ishii et al., 2005a, Hanna and Sollenburger, 2007). Dwarf variety of late-heading type originated from Florida, USA, via Thailand (Mukhtar et al., 2003) was assessed to be suitable for both grazing (Ishii et al., 2005b) and cut-and-carry systems among several sites of southern Kyushu, Japan (Utamy et al., 2011). Dwarf variety of napiergrass meets the requirement of lignocellulose for the biofuel production, because it has low lignin-content and a high herbage mass per year and per area (Rengsirikul et al., 2011). Therefore, we have continued to use this dwarf type of napiergrass for the bio-ethanol (Yasuda et al., 2011) and bio-hydrogen production (Shiragami et al., 2012 ) in University of Miyazaki.

\subsection{Alkali-pretreatment}

The powdered lignocelluloses (30.0 g) were washed with $\mathrm{MeOH}$ to remove lipids and treated with a $1 \%$ aqueous solution of $\mathrm{NaOH}(400 \mathrm{~mL})$ at $95{ }^{\circ} \mathrm{C}$ for $1 \mathrm{~h}$ (Silverstein, et al., 2007). 
The resulting lignin-removed holocellulose was isolated by centrifugation of the solution at 10,000 rpm for $10 \mathrm{~min}$. Lignin remained in the alkali solution. The precipitate was washed by dispersion in water to remove the contaminated lignin. After the $\mathrm{pH}$-adjustment to 7.0, the washed holocellulose was collected by centrifugation and dried.
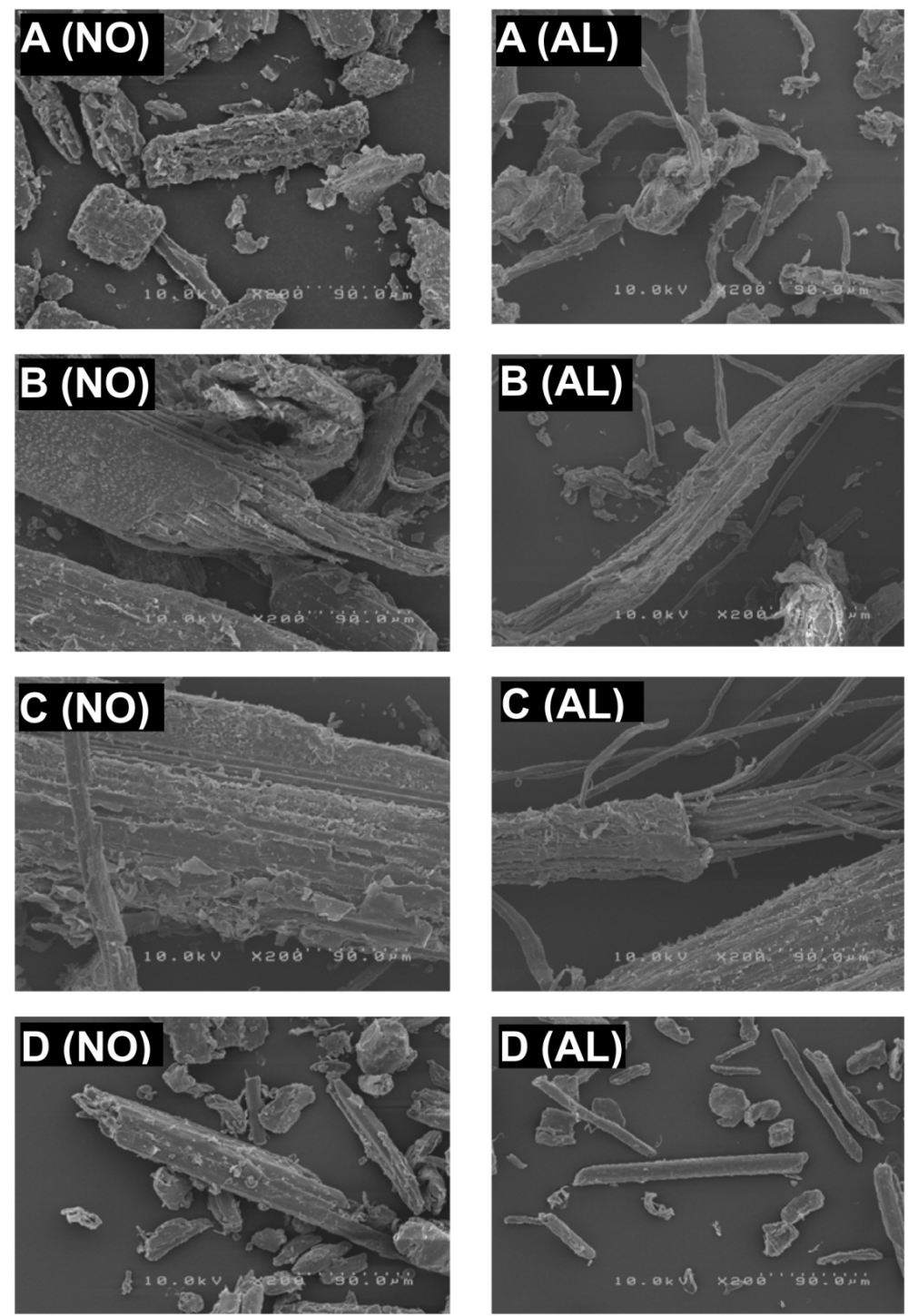

Figure 1. SEM images of non-treated (NO) and alkali-pretreated $(A L)$ napiergrass $(A)$, rice straw $(B)$, silvergrass $(C)$, and bamboo (D). The SEM images were taken under the magnification of 200. 
Physical changes from non-pretreated lignocelluloses to alkali-pretreated lignocelluloses were studied using SEM images, as shown in Fig. 1. The fiber bundles observed in lignocelluloses were unloosened by the removal of lignin to change into the thin fibers in the alkalipretreated lignocelluloses. It was expected that the accessibility of enzyme to the cellulose was increased by the alkali- pretreatment.

\subsection{Lignin-removal effect on saccharification}

The saccharification of alkali-pretreated lignocelluloses (holocellulose, $10.0 \mathrm{~g}$ ) was performed with Acremozyme ( $1.0 \mathrm{~g})$ in an acetate buffer $(60 \mathrm{~mL}, \mathrm{pH} 5.0)$ under vigorous shaking at $45{ }^{\circ} \mathrm{C}$. The amounts of saccharides obtained from $1 \mathrm{~g}$ of alkali-pretreated napiergrass, rice straw, silvergrass, and bamboo were transformed to the amounts per $1.0 \mathrm{~g}$ of the alkaliuntreated samples by multiplication with $0.573,0.613,0.410$, and $0.665 \mathrm{~g} \mathrm{~g}^{-1}$ which were the contents of holocellulose. Table 2 summarizes the amounts of hexose and pentose after the saccharification reaction for the time $\left(T_{\mathrm{SA}}\right)$ to reach the maximum yields. In the cases of napiergrass and rice straw, the hexose yields (87.5 and $81.9 \%$ ) reached almost maximum yields whereas the pentose yields were still low. The largest amount of reducing saccharide was $451 \mathrm{mg}$ obtained from $1.0 \mathrm{~g}$ of rice straw.

In order to examine the effectiveness of alkali-pretreatment, the saccharification of the nonpretreated lignocelluloses (10.0 g) was performed under conditions similar to the case of alkali-pretreated lignocelluloses. The largest amount of reducing saccharide was $307 \mathrm{mg} \mathrm{g}^{-1}$ obtained from non-pretreated napiergrass. Figure 2 shows the time-conversions of the saccharification reactions of non-pretreated and alkali-pretreated lignocelluloses. In all cases, the yields of saccharides from the alkali-pretreated lignocelluloses were higher than those from the non-pretreated lignocelluloses. The ratios $\left(E_{\mathrm{SA}}\right)$ of saccharide yields from the alkalipretreated lignocelluloses to those from the non-pretreated lignocelluloses were used as a measure of the effectiveness of the lignin-removal on the saccharification process. The $E_{\mathrm{SA}}$ values are listed in Table 2.

\subsection{Effectiveness of lignin-removal on Simultaneous Saccharification and Fermentation (SSF)}

Ethanol was produced through a simultaneous saccharification and fermentation process (SSF) under optimal conditions as follows (Yasuda, et al., 2012). Acremozyme (133 mg) in an acetate buffer solution $(3.0 \mathrm{~mL}, \mathrm{pH} 5.0)$ and the cell suspension $(0.16 \mathrm{~mL})$ of S. cerevisiae were added to the suspension of alkali-pretreated lignocelluloses $(1.33 \mathrm{~g})$ in an acetate buffer solution $(5.0 \mathrm{~mL}, \mathrm{pH} 5.0)$. The mixture was reacted at $35^{\circ} \mathrm{C}$ under vigorous stirring until the $\mathrm{CO}_{2}$ evolution ceased. The amounts of the products were transformed to the amounts per $1.0 \mathrm{~g}$ of the alkali-unpretreated lignocelluloses by the dividing by 1.33 and multiplication with 0.573 (napiergrass), 0.613 (rice straw), 0.410 (silvergrass), and $0.665 \mathrm{~g} \mathrm{~g}^{-1}$ (bamboo). Table 3 lists the amounts of ethanol and the recovered hexose and pentose which were determined by averaging the data of seven experiments. The maximum ethanol yield in SSF of alkali-pretreated lignocelluloses was $139 \mathrm{mg} \mathrm{g}^{-1}$ from rice straw. 


\begin{tabular}{|c|c|c|c|c|c|c|}
\hline \multirow[t]{2}{*}{ Lignocelluloses } & \multirow{2}{*}{$\mathrm{PT}^{\mathrm{a})}$} & \multirow{2}{*}{$T_{S A} / h^{b)}$} & \multicolumn{3}{|c|}{ Product ${ }^{c} / \mathrm{mg} \mathrm{g}^{-1}(\text { Yield } / \%)^{\mathrm{d})}$} & \multirow{2}{*}{$E_{S A}$} \\
\hline & & & Hexose & Pentose & Total & \\
\hline \multirow[t]{2}{*}{ Napiergrass } & NO & 120 & $215(57.3)$ & $91(34.3)$ & $307(48.1)$ & \multirow{2}{*}{1.36} \\
\hline & $A L$ & 120 & $328(87.5)$ & $90(34.0)$ & $419(65.7)$ & \\
\hline \multirow[t]{2}{*}{ Rice straw } & NO & 120 & $192(48.4)$ & $51(18.0)$ & $244(35.8)$ & \multirow{2}{*}{1.85} \\
\hline & $A L$ & 120 & $325(81.9)$ & $125(44.0)$ & $451(66.2)$ & \\
\hline \multirow[t]{2}{*}{ Silvergrass } & NO & 120 & $122(35.7)$ & $39(34.2)$ & $161(35.3)$ & \multirow{2}{*}{1.57} \\
\hline & $A L$ & 120 & $178(52.0)$ & $75(65.8)$ & $253(55.5)$ & \\
\hline \multirow[t]{2}{*}{ Bamboo } & NO & 120 & $69(15.7)$ & $19(6.3)$ & $88(11.9)$ & \multirow{2}{*}{3.39} \\
\hline & $A L$ & 120 & $180(41.0)$ & $118(39.3)$ & $297(40.2)$ & \\
\hline
\end{tabular}

a) Pretreatment (PT). NO: non-treatment, AL: lignin removal by alkali-pretreatment.

b) Saccharification time when the total yield of saccharides reached the maximum.

c) The amounts of products per $1 \mathrm{~g}$ of lignocellulosewhen the total yield of saccharides reached the maximum.

d) Yields were based on the amounts of hexose and pentose occurring in lignocelluloses.

Table 2. The lignin removal effects on saccharification processe

\begin{tabular}{|c|c|c|c|c|c|c|}
\hline \multirow{2}{*}{$\begin{array}{l}\text { Lignocelluloses } \\
(\text { EtOH/mg g } \\
\end{array}$} & \multirow{2}{*}{$\mathrm{PT}^{\mathrm{b})}$} & \multirow{2}{*}{$T_{S S F} / h^{c)}$} & \multicolumn{3}{|c|}{ Product $^{\mathrm{d})} / \mathrm{mg} \mathrm{g}^{-1}$} & \multirow{2}{*}{$E_{S S F}$} \\
\hline & & & Hexose & Pentose & EtOH (Yield/\%) e) & \\
\hline \multirow{2}{*}{$\begin{array}{l}\text { Napiergrass } \\
\text { (192) }\end{array}$} & NO & 24 & $18 \pm 5.2$ & $99 \pm 1.6$ & $102 \pm 3.5(53.2)$ & \multirow{2}{*}{1.18} \\
\hline & $A L$ & 96 & $38 \pm 5.3$ & $125 \pm 5.0$ & $121 \pm 4.6(63.1)$ & \\
\hline \multirow{2}{*}{$\begin{array}{l}\text { Rice straw } \\
\text { (203) }\end{array}$} & NO & 24 & $20 \pm 8.0$ & $102 \pm 6.5$ & $96 \pm 5.9(47.3)$ & \multirow{2}{*}{1.45} \\
\hline & $\mathrm{AL}$ & 192 & $27 \pm 7.2$ & $152 \pm 6.2$ & $139 \pm 1.4(68.5)$ & \\
\hline \multirow{2}{*}{$\begin{array}{l}\text { Silvergrass } \\
\text { (175) }\end{array}$} & NO & 24 & $13 \pm 2.2$ & $48 \pm 7.4$ & $41 \pm 9.4(23.5)$ & \multirow{2}{*}{1.77} \\
\hline & $\mathrm{AL}$ & 96 & $12 \pm 3.4$ & $93 \pm 3.5$ & $72 \pm 4.3(41.2)$ & \\
\hline \multirow{2}{*}{$\begin{array}{c}\text { Bamboo } \\
(224)\end{array}$} & NO & 24 & $6 \pm 5.1$ & $18 \pm 5.8$ & $34 \pm 1.7(15.2)$ & \multirow{2}{*}{2.28} \\
\hline & $\mathrm{AL}$ & 96 & $22 \pm 4.3$ & $111 \pm 1.5$ & $78 \pm 5.6(34.8)$ & \\
\hline \multicolumn{7}{|c|}{ a) Theoretical amounts of ethanol obtained from glucan in lignocellulose ( $1 \mathrm{~g})$. } \\
\hline \multicolumn{7}{|c|}{ b) Pretreatment (PT). NO: non-treatment, AL: lignin removal by alkali-pretreatment. } \\
\hline \multicolumn{7}{|c|}{ c) SSF time until the $\mathrm{CO}_{2}$ evolution ceased. } \\
\hline \multirow{2}{*}{\multicolumn{7}{|c|}{$\begin{array}{l}\text { d) The amounts of products per } 1 \mathrm{~g} \text { of lignocellulosewhen the SSF reaction reached the maximum. Data were } \\
\text { determined by averaging the data of seven experiments. }\end{array}$}} \\
\hline & & & & & & \\
\hline \multicolumn{7}{|c|}{ e) Yield of ethanol based on the amounts of hexose occurring in lignocelluloses. } \\
\hline
\end{tabular}

Table 3. The lignin removal effects on SSF processe 

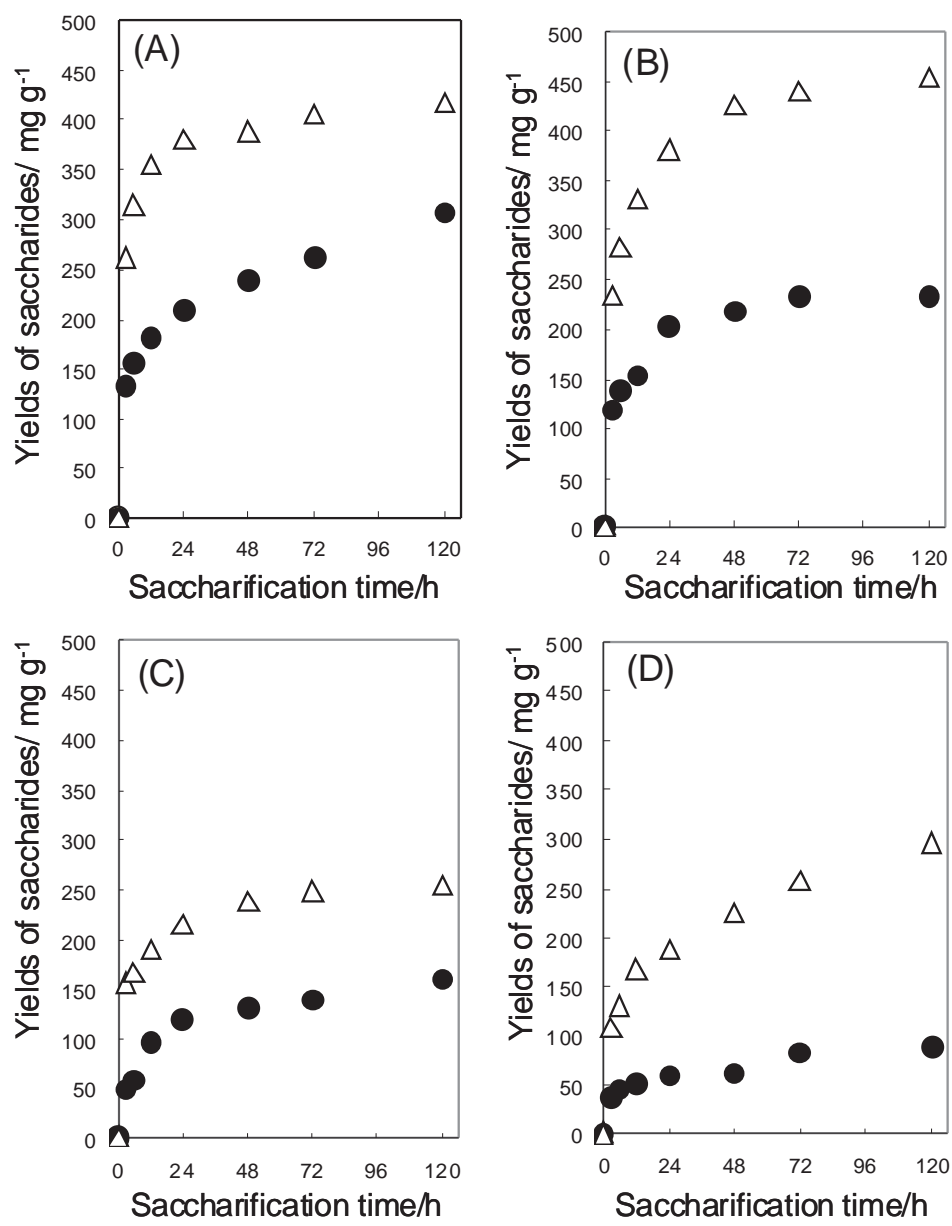

Figure 2. Time conversion of the saccharification of napiergrass (A), rice straw (B), silvergrass (C), and bamboo (D) for the non-pretreated lignocelluloses $(\bullet)$ and the alkali-pretreated lignocelluloses $(\Delta)$. The amounts of sugar from the alkali-pretreated lignocelluloses were transformed to the amounts per $1 \mathrm{~g}$ of the alkali-unpretreated samples by multiplication with 0.573 (napiergrass), 0.613 (rice straw), 0.410 (silvergrass), and $0.665 \mathrm{~g} \mathrm{~g}^{-1}$ (bamboo).

After the SSF, the pentose remained in the solution, although the hexose was consumed by the fermentation with S. cerevisiae. The amounts of pentose was compared between SSF and cellulase-saccharification processes under the optimized conditions. The amounts of pentose formed in SSF were larger than those in saccharification, except for the case of bamboo (Table 2 and 3). Therefore, the SSF process accelerated the hydrolysis of cellulosic components compared to the saccharification process. The consumption of saccharides by fermentation with S. cerevisiae might move the equilibrium to the product side in the hydrolysis of cellulosic components to saccharides with Acremozyme. In the case of bamboo, the ethanol yield 
was low, irrespective of higher content of hexose probably because of poor accessibility of the enzyme to holocellulosic components of bamboo (Yamashita et al., 2010).

Also, the SSF process was applied to the non-pretreated lignocelluloses. The time- conversions of $\mathrm{CO}_{2}$-evolution were compared between non-pretreated and the alkali-pretreated lignocelluloses, as shown in Fig. 3. The yields of ethanol from non- pretreated lignocelluloses were lower compared with the cases from alkali-pretreated lignocelluloses. Among the non-pretreated lignocelluloses, the largest amount of ethanol was $102 \mathrm{mg} \mathrm{g}^{-1}$ obtained from napiergrass. The enhanced effect of SSF yields by alkali-pretreatment was evaluated by the ratio $\left(E_{\mathrm{SSF}}\right)$ of ethanol yields from the alkali-pretreated lignocelluloses to those from non-pretreated lignocelluloses. The $E_{\mathrm{SSF}}$ values are listed in Table 3.

(A)

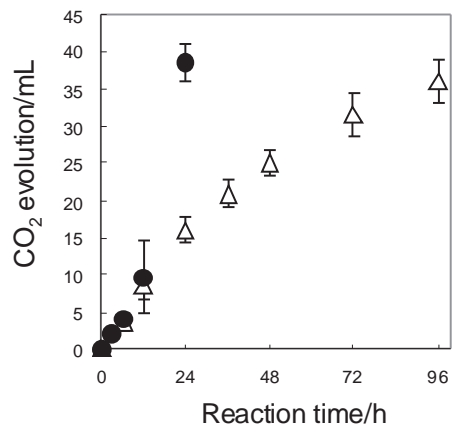

(C)

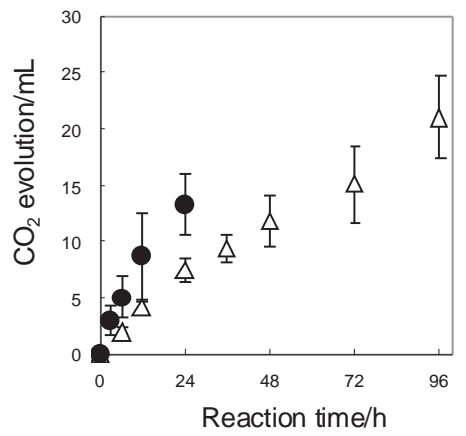

(B)



(D)

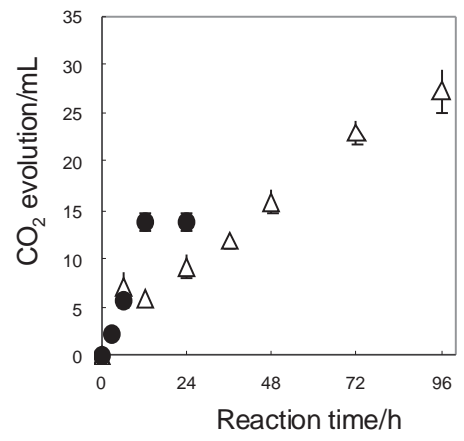

Figure 3. $\mathrm{CO}_{2}$-evolution in the SSF of napiergrass (A), rice straw (B), silvergrass (C), and bamboo (D) for the non-treated lignocelluloses $(\bullet)$ and the alkali-pretreated lignocelluloses $(\Delta)$. The amounts of $\mathrm{CO}_{2}$ from alkali-pretreated lignocelluloses was transformed to the amounts per $1 \mathrm{~g}$ of the alkali-unpretreated samples by multiplication with 0.573 (napiergrass), 0.613 (rice straw), 0.410 (silvergrass), and $0.665 \mathrm{~g} \mathrm{~g}^{-1}$ (bamboo).

It is noteworthy that the SSF of alkali-pretreated lignocelluloses was remarkably slowed down in all cases. In the fermentation by S. cerevisiae of the alkali-pretreated lignocelluloses, a nitrogen-source and a mineral were thought to be insufficient, since the aminoacids and 
the mineral were removed from lignocelluloses by alkali-pretreatment and the additional nutrients were not added in the SSF process (Alfenore et al., 2003). Moreover, the fermentation process was affected by the inhibitory materials derived from the alkali-pretreatment since $T_{\mathrm{SA}}$ of both non-pretreated and the alkali-pretreated lignocelluloses were almost same (Alvira, 2010).

\subsection{Availability of napiergrass as raw materials for ethanol production}

In the cases of rice straw, silvergrass, and bamboo with relatively high lignin-contents (18.2$26.2 \mathrm{wt} \%$ ), the lignin-removal was effective for both saccharification and SSF processes because of the larger $E_{\mathrm{SA}}(1.57-3.39)$ and $E_{\mathrm{SSF}}$ values (1.45-2.28). However, in the case of napiergrass with low lignin-content $(14.9 \mathrm{wt} \%)$, the $E_{\mathrm{SSF}}$ value was small (1.18). Figure 4 shows the plots of the $E_{\mathrm{SSF}}$ values against the lignin-contents of lignocelluloses. As the lignin-contents increased, the $E_{\mathrm{SSF}}$ values gradually increased. From the extrapolation of a fitting line of the plots, it is assumed that the $E_{\mathrm{SSF}}$ values at $13.4 \mathrm{wt} \%$ of lignin-content will reach 1.0 which means no enhancement effect of lignin-removal. Thus, it was elucidated that the alkali-treatment was effective for lignocelluloses with higher lignin content than $13.4 \mathrm{wt} \%$, but was not effective as the pretreatment of lignocelluloses with lower lignin content than $13.4 \mathrm{wt} \%$.



Figure 4. Dependence of $E_{S S F}$ on the lignin contents in the SSF of napiergrass (A), rice straw (B), silvergrass (C), and bamboo (D). The plots showed that the $E_{\mathrm{SSF}}$ value became 1.0 at $13.4 \mathrm{wt} \%$ of lignin content.

\section{Conclusion}

In general, the alkali-pretreatment increases the accessibility of enzymes to the cellulose by the lignin-removal. Therefore alkali-pretreatment is effective for saccarification of the lignocellulose with higher lignin contents. In the case of napiegrass with low lignin- content, 
ethanol was produced in $102 \mathrm{mg} \mathrm{g}^{-1}$ and $121 \mathrm{mg} \mathrm{g}^{-1}$ from napiergrass through the SSF without and with alkali-pretreatment, respectively. Taking into consideration the low effectiveness of lignin-removal in ethanol yield, the retardation of fermentation rate, the loss of nutrients for the fermentation by S. cerevisiae, and the cost of lignin-removal, we concluded that ethanol production from napiergrass should be performed through the SSF process without the alkali-pretreatment. For example, Inoue and his coworkers (Hideno et al., 2009) have recently proposed the enzymatic saccharification of rice straw treated by a wet disk milling method without chemical pretreatment. Even so, the development of a pretreatment method with low energy and low cost to enhance saccharification yields by the structural change of cellulosic components rather than lignin-removal are desired for economically viable bio-ethanol production. In our group, the development of more efficient pretreatment method other than alkali-pretreatment to produce effectively bioethanol from napiergrass is now in progress.

Moreover, the fermentation of the pentose remaining in SSF is important subject. We (Yasuda et al., 2012) started the pentose fermentation using a recombinant Escherichia coli KO11. Pentose fermentation by E. coli KO11 produced additionally $31.4 \mathrm{mg} \mathrm{g}^{-1}$ of ethanol. Under the optimized conditions, the combination of the SSF and KO11 fermentation processes resulted in the production of $144 \mathrm{mg} \mathrm{g}^{-1}$ of ethanol from the non-pretreated napiergrass powder. The ethanol yield was $44.2 \%$ of the theoretical yield based on the hexose $(375 \mathrm{mg}$ ) and pentose $(265 \mathrm{mg}$ ) derived from $1 \mathrm{~g}$ of dry powdered napiergrass.

\section{Acknowledgements}

This study was done as a part of the project entitled "Research and Development of Catalytic Process for Efficient Conversion of Cellulosic Biomass into Biofuels and Chemicals" through Special Funds for Education and Research from the Ministry of Education, Culture, Sports, Science, and Technology of Japan.

\section{Author details}

Masahide Yasuda ${ }^{1}$, Keisuke Takeo ${ }^{1}$, Tomoko Matsumoto ${ }^{2}$, Tsutomu Shiragami ${ }^{1}$, Kazuhiro Sugamoto ${ }^{1}$, Yoh-ichi Matsushita ${ }^{1}$ and Yasuyuki Ishii ${ }^{3}$

1 Department of Applied Chemistry, Faculty of Engineering, University of Miyazaki, Gakuen-Kibanadai Nishi, Miyazaki, Japan

2 Center for Collaborative Research and Community Cooperation, University of Miyazaki, Gakuen-Kibanadai Nishi, Miyazaki, Japan

3 Department of Animal and Grassland Sciences, Faculty of Agriculture, University of Miyazaki, Gakuen-Kibanadai Nishi, Miyazaki, Japan 


\section{References}

[1] Alfenore S, Molina-Jouve C, Guillouet SE, Uribelarrea J-L, Goma G., Benbadis L (2003). Improving ethanol production and viability of Saccharomyces cerevisiae by a vitamin feeding strategy during fed-batch process. Applied Microbiology and Biotechnology 60: 67-72.

[2] Alvira P, Tomás-Pejó E, Ballesteros M, Negro M J (2010). Pretreatment technologies for an efficient bioethanol production process based on enzymatic hydrolysis: A review. Bioresour Technol 101: 4851-4861.

[3] Anderson WF, Dien BS, Brandon SK, Peterson JD (2008). Assessment of bermudagrass and bunch grasses as feedstock for conversion to ethanol. Applied Biochemistry Biotechnology 145: 13-21.

[4] Brandon SK, Sharma LN, Hawkins GM, Anderson WF, Chambliss CK, Doran-Peterson J (2011). Ethanol and co-product generation from pressurized batch hot water pretreated T85 bermudagrass and Merkeron napiergrass using recombinant Escherichia coli as biocatalyst. Biomass Bioenergy 35: 3667-3673.

[5] Cardona CA, Quintero JA, Paz IC (2010). Production of bioethanol from sugarcane bagasse: Status and perspectives. Bioresource Technol 101: 4754-4766 .

[6] Fernell WR, King HK (1953). The simultaneous determination of pentose and hexose in mixtures of sugars. Analyst 78: 80-83 .

[7] Galbe M, Zacchi G. (2007). Pretreatment of lignocellulosic materials for efficient bioethanol production. Advances Biochem Engineering Biotechnol 108: 41-65.

[8] González-García S, Moreira MT, Feijoo G (2010). Environmental performance of lignocellulosic bioethanol production from alfalfa stems. Biofuels Bioprod Bioref 4: 118-131.

[9] Guo G-L, Chen W-H, Ehen W-H, Men L-C, Hwang W-S (2008). Characterization of dilute acid pretreatment of silvergrass for ethanol production. Bioresour Technol 99: 6046-6053.

[10] Hanna WW, Sollenberger LE (2007). Tropical and Subtropical Grasses. (In) Barnes, RF (Eds) Forages Volume II 6th Edition. Blackwell Pub, Iowa USA pp. 245-255.

[11] Hideno A, Inoue H, Tsukahara K, Fujimoto S, Minowa T, Inoue S, Endo T, Sawayama $S$ (2009). Wet disk milling pretreatment without sulfuric acid for enzymatic hydrolysis of rice straw. Bioresour Technol 100: 2706-2711.

[12] Huang C-F, Jiang Y-F, Guo G-L, Hwang W-S (2011). Development of a yeast strain for xylitol production without hydrolysate detoxification as part of the integration of co-product generation within the lignocellulosic ethanol process. Bioresour Technol, 102: 3322-3329. 
[13] Ishii Y, Yamaguchi N, Idota S (2005a). Dry matter production and in vitro dry matter digestibility of tillers among napiergrass (Pennisetum purpureum Schumach) varieties. Grassl Sci 51: 153-163.

[14] Ishii Y, Mukhtar M, Idota S, Fukuyama K (2005b). Rotational grazing system for beef cows on dwarf napiergrass pasture oversown with Italian ryegrass for 2 years after establishment. Grassl Sci 51: 209-220.

[15] Kai T, Tanimura T, Nozaki N, Suiko M, Ogawa K (2010). Bioconversion of soft celluosic resources into sugar and ethanol. Seibutsu-kogaku Kaishi 88: 66-72.

[16] Keshwani DR, Cheng JJ (2009). Switchgrass for bioethanol and other value-added applications: A review. Bioresour Technol 100: 1515-1523.

[17] Kim Y-K, Sakano Y (1996). Analyses of reducing sugars on a thin-layer chromatographic plate with modified Somogyi and Nelson reagents, and with copper bicinchoninate. Biosci Biotechnol Biochem 60: 594-597.

[18] Ko JK, Bak JS, Jung MW, Lee HJ, Choi I-G, Kim TH, Kim KH (2009). Ethanol production from rice straw using optimized aqueous-ammonia soaking pretreatment and simultaneous saccharification and fermentation processes. Bioresour Technol 100: 4374-4380.

[19] Li A-H, Lin C-W, Tran D-T (2011). Optimizing the response surface for producing ethanol from avicel by Brevibacillus strain AHPC8120. J Taiwan Institute of Chemical Engineers 42: 787-792.

[20] Lin C-W, Tran D-T, Lai C-Y, I Y-P, Wu C-H (2010b). Response surface optimization for ethanol production from Pennisetum Alopecoider by Klebsiella oxytoca THLC0409. Biomass and Bioenergy 34: 1922-1929.

[21] Lin C-W, Wu C-H, Tran D-T, Shih M-C, Li W-H, Wu C-F (2011b). Mixed culture fermentation from lignocellulosic materials using thermophilic lignocellulose- degrading anaerobes. Process Biochemistry 46: 489-493.

[22] Mukhtar M, Ishii Y, Tudsri S, Idota S, Sonoda T (2003). Dry matter productivity and overwintering ability in the dwarf and normal napiergrasses as affected by the planting density and cutting frequency. Plant Prod Sci 6: 65-73.

[23] Rengsirikul K, Ishii Y, Kangvansaichol K, Pripanapong P, Sripichitt P, Punsuvon V, Vaithanomsat P, Nakamanee G, Tudsri S (2011). Effects of inter-cutting interval on biomass yield, growth components and chemical composition of napiergrass (Pennisetum purpureum Schumach) cultivars as bioenergy crops in Thailand. Grassl Sci 57: 135-141.

[24] Ryu S, Karim MN (2011). A whole cell biocatalyst for cellulosic ethanol production from dilute acid-pretreated corn stover hydrolyzates. Appl Microbiol Biotechnol 91: 529-542. 
[25] Sathitsuksanoh N, Zhu Z, Ho T-J, Bai M-D, Zhang Y-HP (2010). Bamboo saccharification through cellulose solvent-based biomass pretreatment followed by enzymatic hydrolysis at ultra-low cellulase loadings. Bioresour Technol 101: 4926-4929.

[26] Shiragami T, Tomo T, Tsumagari H, Ishii Y, Yasuda M (2012). Hydrogen evolution from napiergrass by the combination of biological treatment and a Pt-loaded $\mathrm{TiO}_{2}$ photocatalytic reaction. Catalyst 2: 56-67.

[27] Silverstein RA, Chen T, Sharma-Shivappa RR, Boyette MD, Osborne J (2007). A comparison of chemical pretreatment methods for improving saccharification of cotton stalks. Rioresour Tech 98: 3000-3011.

[28] Sluiter A, Hames B, Ruiz R, Scarlata C, Sluiter J, Templaton D, Crocker D (2010). Determination of structural carbohydrates and lignin in biomass, Technical Report NREL/TP-510-42618, National Renewable Energy Laboratory, Golden, CO. http:// www.nrel.gov/biomass/analytical_procedures.html.

[29] Talebnia F, Karakashev D, Angelidaki I (2010). Production of bioethanol from wheat straw: An overview on pretreatment, hydrolysis and fermentation. Bioresour Technol 101: $4744-4753$.

[30] Utamy RF, Ishii Y, Idota S, Harada N, Fukuyama K (2011). Adaptability of dwarf napiergrass under cut-and-carry and grazing systems for smallholder beef farmers in southern Kyushu, Japan. J. Warm Regional Society of Animal Science Japan 54: 65-76.

[31] Yamashita Y. Shono M, Sasaki C, Nakamura Y (2010). Alkaline peroxide pretreatment for efficient enzymatic saccharification of bamboo. Carbohydrate Polymers 79: 914-920.

[32] Yasuda M, Miura A, Yuki R, Nakamura Y, Shiragami T, Ishii Y, Yokoi H (2011). The effect of $\mathrm{TiO}_{2}$-photocatalytic pretreatment on the biological production of ethanol from lignocelluloses. J Photochem Photobiol A: Chem 220: 195-199.

[33] Yasuda M, Miura A, Shiragami T, Matsumoto J, Kamei I, Ishii Y, Ohta K (2012). Ethanol production from non-pretreated napiergrass through a simultaneous saccharification and fermentation process followed by a pentose fermentation with Escherichia coli KO11. J Biol Bioeng 114: 188-192.

[34] Zhang L, Yu CQ, Shimojo M, Shao T (2011). Effect of different rates of ethanol additive on fermentation quality of napiergrass (Pennisetum purpureum). Asian-Australasian J Animal Sci 24: 636-642. 